\title{
KATEGORI SISTEM PEMERINTAHAN
}

\author{
Nama Mahasiswa : Karmila \\ Email : karmilapulungan@gmail.com \\ No BP : 1910003600250 \\ Perguruan Tinggi : Universitas Ekasakti_AAI Padang
}

\subsection{Pendahuluan}

Sistem pemerintahan adalah suatu tatanan utuh yang terdiri atas berbagai komponen yang bekerja saling bergantung dan mempengaruhi dalam mencapai tujuan dan fungsi pemerintahan.

Sesuai dengan kondisi negara masing-masing, sistem ini dibedakan menjadi :

1. Sistem presidensial (presidensil), atau disebut juga dengan sistem kongresional, merupakan sistem pemerintahan negara republik di mana kekuasaan eksekutif dipilih melalui pemilu dan terpisah dengan kekuasan legislatif.

2. Sistem parlementer atau sebuah sistem pemerintahan yang parlemennya memiliki peranan penting dalam pemerintahan. Dalam hal ini parlemen memiliki wewenang dalam mengangkat perdana menteri dan parlemen pun dapat menjatuhkan pemerintahan, yaitu dengan cara mengeluarkan semacam mosi tidak percaya. Berbeda dengan sistem presidensiil, sistem parlemen dapat memiliki seorang presiden dan seorang perdana menteri, yang 
berwenang terhadap jalannya pemerintahan. Dalam presidensiil, presiden berwenang terhadap jalannya pemerintahan, tetapi dalam sistem parlementer presiden hanya menjadi simbol kepala negara saja.

3. Sistem Semipresidensial atau sistem pemerintahan yang menggabungkan kedua sistem pemerintahan presidensial dan parlementer.

Sistem pemerintahan semipresidensial dapat pula dikatakan dengan dual eksekutif atau eksekutif ganda. Sistem presidensial (presidensiil) atau sistem kongresional merupakan sistem pemerintahan negara republik yang mana kekuasaan eksekutif dipilih dengan pemilu dan terpisah dengan kekuasaan legislatif.

4. Negara komunis atau istilah politik yang digunakan untuk mendeskripsikan bentuk pemerintahan suatu negara yang menganut sistem satu partai dan mendeklarasikan kesetiaan kepada komunisme (Marxisme, Leninisme, atau Maoisme).

5. Demokrasi Liberal atau Demokrasi konstitusional adalah sistem politik yang menganut kebebasan individu. Secara konstitusional, ini dapat diartikan sebagai hak-hak individu dari kekuasaan pemerintah Semasa Perang Dingin, istilah demokrasi liberal bertolak belakang dengan komunisme ala Republik Rakyat.

6. Liberal adalah. sistem politik yang menganut kebebasan individu. secara konstitusional hak hak individu dari kekuasaan pemerintah. 
Sistem pemerintahan mempunyai sistem dan tujuan untuk menjaga suatu kestabilan negara itu. Namun di beberapa negara sering terjadi tindakan separatisme karena sistem pemerintahan yang dianggap memberatkan rakyat ataupun merugikan rakyat. Sistem pemerintahan mempunyai fondasi yang kuat di mana tidak bisa diubah dan menjadi statis. Jika suatu pemerintahan mempunya sistem pemerintahan yang statis, absolut maka hal itu akan berlangsung selama-lamanya hingga adanya desakan kaum minoritas untuk memprotes hal tersebut.

Secara luas berarti sistem pemerintahan itu menjaga kestabilan masyarakat, menjaga tingkah laku kaum mayoritas maupun minoritas, menjaga fondasi pemerintahan, menjaga kekuatan politik, pertahanan, ekonomi, keamanan sehingga menjadi sistem pemerintahan yang kontinu dan demokrasi di mana seharusnya masyarakat bisa ikut turut andil dalam pembangunan sistem pemerintahan tersebut. Hingga saat ini hanya sedikit negara yang bisa mempraktikkan sistem pemerintahan itu secara menyeluruh.

Secara sempit, sistem pemerintahan hanya sebagai sarana kelompok untuk menjalankan roda pemerintahan guna menjaga kestabilan negara dalam waktu relatif lama dan mencegah adanya perilaku reaksioner maupun radikal dari rakyatnya itu sendiri. 


\subsection{Rumusan Masalah}

1. Mengapa sistem presindensil yang di terapkan di Indonesia?

2. Kenapa hanya tiongkok yang menganut sistem komunis?

3. Kenapa sistem pemerintahan liberal cocok tidak di terapkan di indonesia?

\subsection{Pembahasan}

Sistem pemerintahan adalah suatu tatanan utuh yang terdiri atas berbagai komponen yang bekerja saling bergantung dan mempengaruhi dalam mencapai tujuan dan fungsi pemerintahan

Sistem pemerintahan mempunyai sistem dan tujuan untuk menjaga suatu kestabilan negara itu. Namun di beberapa negara sering terjadi tindakan separatisme karena sistem pemerintahan yang dianggap memberatkan rakyat ataupun merugikan rakyat. Sistem pemerintahan mempunyai fondasi yang kuat di mana tidak bisa diubah dan menjadi statis. Jika suatu pemerintahan mempunya sistem pemerintahan yang statis, absolut maka hal itu akan berlangsung selama-lamanya hingga adanya desakan kaum minoritas untuk memprotes hal tersebut.

Secara luas berarti sistem pemerintahan itu menjaga kestabilan masyarakat, menjaga tingkah laku kaum mayoritas maupun minoritas, menjaga fondasi pemerintahan, menjaga kekuatan politik, pertahanan, ekonomi, keamanan sehingga menjadi sistem pemerintahan yang kontinu dan demokrasi di mana seharusnya 
masyarakat bisa ikut turut andil dalam pembangunan sistem pemerintahan tersebut. Hingga saat ini hanya sedikit negara yang bisa mempraktikkan sistem pemerintahan itu secara menyeluruh.

Secara sempit, sistem pemerintahan hanya sebagai sarana kelompok untuk menjalankan roda pemerintahan guna menjaga kestabilan negara dalam waktu relatif lama dan mencegah adanya perilaku reaksioner maupun radikal dari rakyatnya itu sendiri :

1. Mengapa sistem presindensil yang di terapkan di Indonesia?

Karena Indonesia merupakan salah satu negara yang menganut sistem pemerintahan presidensial, yang mana seorang presiden merupakan pemimpin tunggal (kekuasaan tertinggi) di tanah air ini. Sebagaimana diatur dalam Pasal 4 Ayat 1 UUD 1945 yang berbunyi "Bahwa Presiden Republik Indonesia memegang penuh kekuasaan pemerintahan menurut Undang Undang Dasar". Sistem pemerintahan presidensial (sistem kongresional) yaitu sistem pemerintahan dimana kedudukan yang independen dimiliki oleh badan eksekutif dan legislatif.

Ciri-ciri pemerintahan presidensial :

a. Kepala pemerintahan dan kepala negara adalah presiden.

b. Presiden dapat memberhentikan dan mengangkat para menteri-menteri yang hanya bertanggung jawab pada kekuasaan eksekutif .

c. Kekuasaan eksekutif tidak bertangung jawab terhadap legislatif.

d. Kekuasaan eksekutif terpisah dengan legislatif. 
e. Melalui badan perwakilan rakyat, rakyat dapat memilih Presiden.

f. Kekuasaan legislatif dan lembaga perwakilan dimiliki oleh parlemen.

g. Rakyat memilih langsung anggota parlemen.

Pokok-pokok sistem pemerintahan Indonesia sekarang :

a. Republik merupakan bektuk pemerintahan.

b. Sistem yang di anut adlah sistem pemerintah presidensial.

c. Bentuk negara kesatuan yang dimiliki prinsip otonomi daerah yang luas.

d. Wilayah negara terbagi menjadi beberapa provinsi.

Sistem pemerintahan Indonesia sebelum amandemen diantara lain :
a. Sistem konstitusional
b. Indonesia merupakan negara yang berdasarkan atas hukum.
c. Kekuasaan tinggi negara berada di tangan MPR.
d. Kekuasaan kepala negara tidak tak terbatas.
e. Presiden tidak bertanggung jawab kepada DPR.

2. Kenapa hanya tiongkok yang menganut sistem komunis?

Pada awalnya tiongkok merupakan negara kerajan,namun berkat jasa dr,Sun Yat Sen pemerintahanya diubah menjadi pemerintahan modern dengan sistem pemerintahan nasionalis atau demokrasi.Namun Mao Tse Tung kemudian mengambil alih kekuasaan dan mengubahnya menjadi negara komunis. Perubahan sistem pemerintahan Tiongkok menjadi negara komunis disebabkan karena adanya 
penggulingan pemerintahan Partai Nasionalis Tiongkok oleh Partai Komunis Tiongkok. Pemerintah Nasionalis Tiongkok pindah ke pulau taiwan dan mendirikan ibukota di Taipei. Kemudian pemerintah komunis mendirikan pemerintahan di seluruh negara Tiongkok (termasuk Taiwan) dan pemerintahan nasionalis di Taiwan tidak diakui.

Komunisme adalah ideologi yang berkenaan dengan filosofi, politik, sosial, dan ekonomi yang tujuan utamanya terciptanya masyarakat komunis dengan aturan sosial ekonomi berdasarkan kepemilikan bersama alat produksi dan tidak adanya kelas sosial, uang,dan negara.

Istilah komunisme sering dicampur adukkan dengan Komunis Internasional. Komunisme atau Marxisme adalah ideologi dasar yang umumnya digunakan oleh partai komunis di seluruh dunia. sedangkan komunis internasional merupakan racikan ideologi ini berasal dari pemikiran Lenin sehingga dapat pula disebut "Marxisme-Leninisme".

Dalam komunisme, perubahan sosial harus dimulai dari pengambil alihan alatalat produksi melalui peran Partai Komunis. Logika secara ringkasnya, perubahan sosial dimulai dari buruh atau yang lebih dikenal dengan proletar, tetapi pengorganisasian Buruh hanya dapat berhasil dengan melalui perjuangan partai. Partai membutuhkan peran Politbiro sebagai think-tank. Dapat diringkas perubahan sosial hanya bisa berhasil jika dicetuskan oleh Politbiro.

Komunisme sebagai anti-kapitalisme menggunakan sistem partai komunis sebagai alat pengambil alihan kekuasaan dan sangat menentang 
kepemilikan akumulasi modal pada individu. pada prinsipnya semua adalah direpresentasikan sebagai milik rakyat dan oleh karena itu, seluruh alat-alat produksi harus dikuasai oleh negara guna kemakmuran rakyat secara merata, Komunisme memperkenalkan penggunaan sistem demokrasi keterwakilan yang dilakukan oleh elit-elit partai komunis oleh karena itu sangat membatasi langsung demokrasi pada rakyat yang bukan merupakan anggota partai komunis karenanya dalam paham komunisme tidak dikenal hak perorangan sebagaimana terdapat pada paham liberalisme.

Ideologi komunisme di Tiongkok agak lain daripada dengan MarxismeLeninisme yang diadopsi bekas Uni Soviet. Mao Zedong menyatukan berbagai filsafat kuno dari Tiongkok dengan Marxisme yang kemudian ia sebut sebagai Maoisme. Perbedaan mendasar dari komunisme Tiongkok dengan komunisme di negara lainnya adalah bahwa komunisme di Tiongkok lebih mementingkan peran petani daripada buruh. Ini disebabkan karena kondisi Tiongkok yang khusus di mana buruh dianggap sebagai bagian tak terpisahkan dari kapitalisme.

Banyak orang yang mengira komunisme "mati" setelah Revolusi 1989 yang berakhir pada bubarnya Uni Soviet dua tahun kemudian, yang diawali dengan keputusan Presiden Mikhail Gorbachev. Namun demikian, setelah runtuhnya Uni Soviet dan pecahnya Yugoslavia, terdapat beberapa negara yang masih dipimpin oleh pemerintahan Marxis-Leninis dengan partai tunggal. Di antaranya adalah Kuba, Laos, Vietnam, dan Republik Rakyat Tiongkok. Korea Utara menyebut ideologinya sebagaiJuche, yang mereka anggap sebagai perkembangan dari 
Marxisme-Leninisme. Meskipun demikian, Tiongkok, Laos, Vietnam, dan Kuba telah mengubah sistem ekonominya menjadi lebih terbuka. Di India, komunis memimpin pemerintahan di tiga negara bagian. Sementara di Nepal, partai komunis menjadi mayoritas di parlemen.

Partai-partai komunis dan Marxis-Leninis lainnya juga mendapat kursi dalam parlemen di berbagai negara, walaupun tidak memimpin pemerintahan. Di antaranya Jepang, Rusia, Venezuela, dan Israel.

3. Kenapa sistem pemerintahan liberal tidak coco di terapkan di Indonesia?

Demokrasi Liberal merupakan suatu konsep yang terdiri dari Demokrasi dan Liberalisme. Demokrasi adalah sistem pemerintahan dimana kekuasaan berada di tangan rakyat. Sedangkan Liberalisme adalah Ideologi dimana setiap Individu memiliki kebebasan yang tak terbatas. Kedua konsep ini jika dilihat memiliki kesamaan dan saling keterhubungan. Baik Demokras maupun Liberalisme sama-sama lahir di Eropa. Meskipun Demokrasi sendiri lahir lebih awal dibandingkan Liberalisme. Kesamaan lain dari 2 konsep ini adalah sama-sama bertumpu pada kebebasan.

Penerapan daripada Demokrasi Liberal di Indonesia Berawal dari masa revolusi Kemerdekaan Indonesia. setelah Indonesia didirikan melalui proklamasi kemerdekaan, Tentara sekutu datang ke wilayah Indonesia. tujuan mereka adalah memberantas unsur fasisme Jepang. Soekarno dan rekan-rekannya dianggap sebagai antek Jepang. Bahkan negara Indonesia yang dikonsep oleh Sukarno dan Kawan- 
kawan, oleh Belanda dianggap sebagai negara bonek fasis buatan Jepang. Merujuk pada UUD 1945 yang terlihat sama dengan Konstitusi Jepang. Bahkan bendera merah putih indonesia disamakan dengan Bendera Matahari milik Jepang.

Untuk menghindari stigma Negara Fasis, maka munculah tokoh muda bernama Sutan Sjahrir. Beliau memiliki latar belakang yang sama dengan Mohammad Hatta. Selain berdarah minang, beliau juga pernah mengenyam pendidikan di Belanda. meski demikian, beliau berbeda pandangan dengan Sukarno dan Hatta. Sjahrir tidak koperatif dengan Jepang. Sukarno, Hatta dan Sjahrir Setuju dengan rencana Sjahrir yang melakukan pergerakan bawah tanah menentang Jepang sementara Sukarno dan Hatta bekerja sama dengan Jepang (Mrazaek, 1994: 222).

Demokrasi Liberal diharapkan akan membangun negera Indonesia layaknya negara-negara Eropa. Sayangnya, pembangunan yang diharapkan tidak berjalan dengan lancar. Kabinet-kabinet yang ditunjuk untuk bekerja mengalami jatuh bangun. Setiap kabinet jatuh, pembangunan yang dilaksanakan langsung dihentikan dan diganti dengan program baru.

Pada tanggal 21 Februari 1957 Presiden Soekarno mengajukan gagasan yang dikenal sebagai Konsepsi Presiden. Jika dilihat dari isinya, Konsepsi presiden merupakan wacana Sukarno untuk mengakhiri praktek Demokrasi Liberal. Isi pokok dari Konsepsi Presiden tersebut adalah sebagai berikut :

a. Sistem demokrasi liberal-parlementer perlu diganti dengan demokrasi terpimpin. 
b. Perlu dibentuk Kabinet Gotong Royong yang merupakan kabinet kaki empat, yakni: PNI, Masyumi, NU, dan PKI.

c. Perlu dibentuk Dewan Nasional yang anggotanya terdiri dan golongan fungsional dalam masyarakat.

Oleh Karena Indonesia membentuk negara yang bersifat presidensil yang mengedepankan bhineka tunggal ika yang begitu homogen dan komplek dalam kehidupan budayanya dan menjung-jung tinggi musyawarah untuk mencapai mufakat,yang mendahulukan kepentingan umum dari pada kepentingan pribadi. tentu bertentangan dengan azas demokrasi liberal selain itu demokrasi pancasila harus dibudidayakan kepada anak cucu kita nantinya. 


\subsection{Penutup}

Kesimpulannya setiap negara memiliki sistem pemerintahannya masing-masing yang dimana sistem pemerintahan yang meraka anut sesuai dengan keadaan masyarakat atau rakyatnya.sebagaimana negara tionghoa atau negara tirai bambu meraka menganut sistem pemerintahan komunisme yang dimana agama apapun tidak boleh berdiri di situ padahal hal itu bertentangan dengan nrgara kita yaitu Indonesia yang mana menganut sistem pemerintahan presidensil yang dimana bentuk pemerintahannya adalah republic sedangkan sistem pemerintahannya presidensil yang mana dasar negara adalah Pancasila yang terdapat pada sila pertama yang berbunyi ketuhanan yang maha esa maknanya adalah percaya dan taqwa kepada tuhan yang maha esa dengan agama dan kepercayaannya masing-masing munurut dasar kemanusian yang adil dan beradap dan hormat menghormati serta kerja sama antar pemeluk agama dan penganut-penganut kepercayaan yang berbeda-beda sehingga terbina kerukunan hidup.

\section{Daftar Pustaka}

Andrew Shandy Utama, Independensi Pengawasan Terhadap Bank Badan Usaha Milik Negara (Bumn) Dalam Sistem Hukum Nasional Di Indonesia, 
Soumatera Law Review, Volume 1, Nomor 1, 2018, 10.22216/soumlaw.v1i1.3312.

Annisa Arifka, Sanksi Administrasi Bagi Wajib Pajak Pajak Penghasilan Orang Pribadi Di Kota Padang, Soumatera Law Review, Volume 1, Nomor 2, 2018, 10.22216/soumlaw.v1i2.3745.

Ade Sarmini, Kualitas Pelayanan Surat Izin Mengemudi (SIM) Pada Kantor Satuan Lalu Lintas Polres Karimun, Soumatera Law Review, Volume 2, Nomor 2, 2019, 10.22216/soumlaw.v2i2.4231.

Bram Mohammad Yasser, Pengujian Unsur Penyalahgunaan Wewenang Pada Peradilan Tata Usaha Negara Dalam Kaitannya Dengan Tindak Pidana Korupsi, Soumatera Law Review, Volume 2, Nomor 1, 2019, 10.22216/soumlaw.v2i1.3558.

Danel Aditia Situngkir, Asas Legalitas Dalam Hukum Pidana Nasional Dan Hukum Pidana Internasional, Soumatera Law Review, Volume 1, Nomor 1, 2018, 10.22216/soumlaw.v1i1.3398.

Darmini Roza, Laurensius Arliman S, Peran Pemerintah Daerah Di Dalam Melindungi Hak Anak Di Indonesia, Masalah-Masalah Hukum, Volume 47, Nomor 1, 2018. https://doi.org/10.14710/mmh.47.1.2018.10-21.

Darmini Roza, Laurensius Arliman S, Peran Pemerintah Daerah untuk Mewujudkan Kota Layak Anak di Indonesia, Ius Quia Iustum Law Journal, Volume 25, Nomor 1, 2018, https://doi.org/10.20885/iustum.vol25.iss1.art10. 
Darmini Roza, Laurensius Arliman S, Peran Badan Permusyawaratan Desa di Dalam Pembangunan Desa dan Pengawasan Keuangan Desa, Padjadjaran Journal of Law, Volume 4, Nomor 3, 2017. https://doi.org/10.15408/jch.v4i2.3433.

Debora Angelia Pardosi, Peran Jabatan Fungsional Auditor Terhadap Peningkatan Kinerja Birokrat Di Lingkungan Inspektorat Provinsi Jawa Tengah, Soumatera Law Review, Volume 1, Nomor 2, 2018, 10.22216/soumlaw.v1i2.3718.

Dewi Fiska Simbolon, Kurangnya Pendidikan Reproduksi Dini Menjadi Faktor Penyebab Terjadinya Pelecehan Seksual Antar Anak, Soumatera Law Review, $\quad$ Voume $\quad 1, \quad$ Nomor $\quad 1, \quad 2017$, http://doi.org/10.22216/soumlaw.v1i1.3310.

Dian Bakti Setiawan, Keberadaan Dan Penerapan Peraturan Daerah Syari'ah Sebagai Perundang-Undangan Pada Tingkat Daerah, Soumatera Law Review, Volume 1, Nomor 1, 2018, 10.22216/soumlaw.v1i1.3327.

Dila Andika Azhar, Analisis Yuridis Terhadap Penyimpanan Sertifikat Hak Atas Tanah Oleh Notaris Pada Proses Pengikatan Jual Beli (Pjb) (Analisis Putusan Nomor 53/Pid.B/2017/Pn.Bkt), Soumatera Law Review, Volume 2, Nomor 1, 2019, 10.22216/soumlaw.v2i1.3557.

Dola Riza, Hakikat KTUN Menurut Undang-undang Peradilan Tata Usaha Negara Vs Undang-undang Admnistrasi Pemerintahan, Soumatera Law Review, Volume 2, Nomor 2, 2019, 10.22216/soumlaw.v2i2.3566. 
Fadlan, Perkembangan Kebijakan Daerah Sebagai Paradigma Dasar Untuk Penentuan Kebijakan Mengelola Potensi Keberagaman, Soumatera Law Review, Volume 2, Nomor 1, 2019, 10.22216/soumlaw.v2i1.3347.

Ferdian, Lelang Terhadap Objek Jaminan Fidusia Yang Dirampas Oleh Negara Berdasarkan Putusan Pengadilan Negeri Di Kantor Pelayanan Kekayaan Negara Dan Lelang Padang, Soumatera Law Review, Volume 2, Nomor 1, 2019, 10.22216/soumlaw.v2i1.3564.

Hasnati, Tanggung Jawab Direksi Terhadap Terjadinya Kredit Macet Pada Perbankan Berdasarkan Undang-Undang Nomor 40 Tahun 2007, Soumatera Law Review, Volume 2, Nomor 1, 2019, 10.22216/soumlaw.v2i1.3319.

Hendra Sudrajat, Beggy Tamara, Peran Naskah Akademik Dan Daftar Inventarisasi Masalah Dalam Mewujudkan Peraturan Daerah Nomor 2 Tahun 2015 Tentang Perlindungan Anak Yang Aspiratif Di Kota Tangerang, Soumatera Law Review, Volume 1, Nomor 2, 2018, 10.22216/soumlaw.v1i2.3713. Idham, Pendaftaran Tanah Dan Penerbitan Sertipikat Dalam Perspektif Free Trade Zone (FTZ) Di Kampung Tua, Kota Batam, Provinsi Kepulauan Riau, Soumatera Law Review, Volume 2, Nomor 1, 2019, 10.22216/soumlaw.v2i1.3908.

Jasmir, Pengembalian Status Hukum Tanah Ulayat Atas Hak Guna Usaha, Soumatera Law Review, Volume 1, Nomor 1, 2018, 10.22216/soumlaw.v1i1.3384. 
Laurensius Arliman S, Lembaga-Lembaga Negara (Di Dalam Undang-Undang Dasar Negara Republik Indonesia Tahun 1945), Deepublish, Yogyakarta, 2016.

Laurensius Arliman S, Perlindungan Anak (Dari Undang-Undang Perlindungan Anak, Undang-Undang Sistem Peradilan Pidana Anak, Wacana Kebiri Dan Bahaya LGBT Bagi Regenarasi Bangsa), Deepublish, Yogyakarta, 2016.

Laurensius Arliman S, Gokma Toni Parlindunga S, Politik Hukum Perlindungan Anak, Deepublish, Yogyakarta, 2017.

Laurensius Arliman S, Kedudukan KPAI dalam Struktur Ketatanegaraan Republik Indonesia, Deepublish, Yogyakarta, 2019.

Laurensius Arliman S, Pendidikan Kewarganegaraan - Tantangan Warga Negara Milineal Menghadapi Revolusi Industri 4.0, Yogyakarta, 2019.

Laurensius Arliman S, Protection of Girls from the Dangers of Sexual Violence in Indonesia to Design Suistanable Child Protection, Proceedings 1st Bicoshs (Prophetic Role of Sharia Knowledge in Developing Social Justice), 2017.

Laurensius Arliman S, Debora Angelina Carissa Pardosi, Peran Badan Pengawas Pemilu untuk Mengisi Kekosongan Hukum Eksploitasi Anak dalam Pelaksanaan Kampanye, Seminar Nasional Hukum Universitas Negeri Semarang, $\quad$ Volume $\quad$ 4, Nomor $\quad 2, \quad 2018$, https://doi.org/10.15294/snh.v4i02.25600.

Laurensius Arliman S, Danel Situngkir, Rianda Putri, Rahmat Fauzi, Hariyadi, Gokma Toni Parlindungan S, Cyber Bullying Against Children In Indonesia, 
International Conference on Social Sciences, Humanities, Economics and Law; Padang, 2018. DOI:10.4108/eai.5-9-2018.2281372.

Laurensius Arliman S, Penelantaran Perlindungan Anak Oleh Orangtua Akibat Gaya Hidup Modernisasi Yang Salah Arah, Konferensi Nasional Sosiologi V, Asosiasi Program Studi Sosiologi Indonesia, Volume 5, Padang 18-19 Mei 2017.

Laurensius Arliman S, Penegakan Hukum Bisnis Ditinjau Dari Undang-Undang Larangan Praktek Monopoli Dan Persaingan Usaha Tidak Sehat, Lex Jurnalica, Volume 16, Nomor 3, 2019.

Laurensius Arliman S, Analisis Dari Perspektif Politik Hukum Terhadap Pasal 56 Undang-Undang Nomor 8 Tahun 1981 Tentang Kitab Undang Undang Hukum Acara Pidana, Lex Jurnalica, Volume 15, Nomor 3, 2018.

Laurensius Arliman S, Perlindungan Hukum Terhadap Karya Desain Industri Di Indonesia, Lex Jurnalica, Volume 15, Nomor 2, 2018.

Laurensius Arliman S, Perlindungan Hak Anak Di Dalam Memperoleh Pelayanan Kesehatan Di Indonesia, Lex Jurnalica, Volume 15, Nomor 1, 2018.

Laurensius Arliman S, Perlindungan Hak Anak Yang Berhadap Dengan Hukum Di Wilayah Hukum Polisi Resort Kota Sawahlunto, Lex Jurnalica, Volume 14, Nomor 2, 2018.

Laurensius Arliman S, Kedudukan Lembaga Perlindungan Saksi Dan Korban Terhadap Perlindungan Hak Anak Yang Bekelanjutan Di Indonesia, Lex Jurnalica, Volume 14, Nomor 1, 2018. 
Laurensius Arliman S, Perlindungan Hukum UMKM Dari Eksploitasi Ekonomi Dalam Rangka Peningkatan Kesejahteraan Masyarakat, Jurnal RechtsVinding, Volume 6, Nomor 3, 2017.

Laurensius Arliman S, Partisipasi Masyarakat Di Dalam Perlindungan Anak Yang Berkelanjutan Sebagai Bentuk Kesadaran Hukum, Padjadjaran Journal of Law, Volume 3, Nomor 2, 2016. https://doi.org/10.22304/pjih.v3n2.a5.

Laurensius Arliman S, Penanaman Modal Asing Di Sumatera Barat Berdasarkan Undang-Undang Nomor 25 Tahun 2007 Tentang Penanaman Modal, Supremasi Hukum, Volume 1, Nomor $\quad 1, \quad 2018$. http://dx.doi.org/10.36441/hukum.v1i01.102.

Laurensius Arliman S, Kodifikasi RUU KUHP Melemahkan Komisi Pemberantasan Korupsi, UIR Law Review, Volume 2, Nomor 1, 2018 https://doi.org/10.25299/uirlrev.2018.2.01.1437.

Laurensius Arliman S, Perlindungan Hukum Terhadap Anak Yang Tereksploitasi Secara Ekonomi Di Kota Padang, Jurnal Arena Hukum, Volume 9, Nomor 1, 2016, https://doi.org/10.21776/ub.arenahukum.2016.00901.5

Laurensius Arliman S dan Hariyadi, Peran Orangtua Dalam Mengawasi Anak Dalam Mengakses Media Internet Untuk Mewujudkan Perlindungan Hak Anak, Soumatera Law Review, Volume 1, Nomor 2, 2018, http://doi.org/10.22216/soumlaw.v1i2.3716. 
Laurensius Arliman S, Peran Investasi dalam Kebijakan Pembangunan Ekonomi Bidang Pariwisata di Provinsi Sumatera Barat, Kanun Jurnal Ilmu Hukum, Volume 20, Nomor 2, 2018, https://doi.org/10.24815/kanun.v20i2.10081.

Laurensius Arliman S, Perlindungan Hukum Bagi Anak Dalam Perspektif Pancasila Dan Bela Negara, Jurnal Ilmu Hukum Unifikasi, Volume 5, Nomor 1, 2018, https://doi.org/10.25134/unifikasi.v5i1.754.

Laurensius Arliman S, Hukum Adat Di Indonesia Dalam Pandangan Para Ahli Dan Konsep Pemberlakuannya di Indonesia, Jurnal Selat, Volume 5, Nomor 2, 2018, https://doi.org/10.31629/selat.v5i2.320.

Laurensius Arliman S, Perkembangan Dan Dinamika Hukum Ketenagakerjaan Di Indonesia, Jurnal Selat, Volume 5, Nomor 1, 2017.

Laurensius Arliman S, Peran Pemerintah Daerah Dalam Perlindungan Hak Anak Berdasarkan Undang-Undang Nomor 35 Tahun 2014 Tentang Perlindungan Anak, Jurnal Yustisia, Volume 22, Nomor 1, 2015.

Laurensius Arliman S, Eksistensi Hukum Lingkungan dalam Membangun Lingkungan Sehat Di Indonesia, Jurnal Lex Librum, Volume 5, Nomor 1, 2018, http://doi.org/10.5281/zenodo.1683714.

Laurensius Arliman S, Perlindungan Anak Oleh Masyarakat Ditinjau Dari Mazhab Sejarah Di Dalam Penerapan Prinsip The Best Interest Of The Child Pada Kehidupan Anak Di Indonesia, Era Hukum-Jurnal Ilmiah Ilmu Hukum, $\begin{array}{llll}\text { Volume } & \text { Nomor } & 15, & \text { No17, }\end{array}$ http://dx.doi.org/10.24912/era\%20hukum.v15i1.668. 
Laurensius Arliman S, Reformasi Penegakan Hukum Kekerasan Seksual Terhadap Anak Sebagai Bentuk Perlindungan Anak Berkelanjutan, Kanun Jurnal Ilmu Hukum, Volume 19, Nomor 2, 2017.

Laurensius Arliman S, Tinjauan Kedudukan Pengguna Anggaran Dan Kuasa Pengguna Anggaran, Volume 8, Nomor 2, 2015, https://doi.org/10.21776/ub.arenahukum.2015.00802.1

Laurensius Arliman S, Penyelesaian Konflik Antar Umat Beragama (Studi Pada Komnas HAM Perwakilan Sumatera Barat), Padjadjaran Jurnal Ilmu Hukum, 2015 ,

Laurensius Arliman S, Imelda Tamba, Maria Florida Bunga Makin, Kualitas Pelayanan Sdm Mempengaruhi Kepuasan Anggota Koperasi Simpan Pinjam Credit Union Jembatan Kasih Kp Tanjung Uncang Di Kota Batam, Jurnal Marketing, Volume 1, Nomor 1, 2018.

Laurensius Arliman S, Fungsi Badan Kehormatan Dewan Perwakilan Rakyat Daerah Kota Padang, Jurnal Ilmiah Hukum De’Jure, Volume 1, Nomor 2, 2017.

Laurensius Arliman S, Urgensi Notaris Syari'ah Dalam Bisnis Syariah Di Indonesia, Walisongo: Jurnal Penelitian Sosial Keagamaan, Volume 24, Nomor 1, Mei 2016, DOI: http://dx.doi.org/10.21580/ws.2016.24.1.676.

Laurensius Arliman S, Pendidikan Paralegal Kepada Masyarakat Sebagai Bentuk Perlindungan Anak Yang Berkelanjutan, UIR Law Review, Volume 1, Nomor 1, 2017, https://doi.org/10.25299/ulr.2017.1.01.153 
Laurensius Arliman S, Peran Lembaga Catatan Sipil Terhadap Perkawinan Campuran Berdasarkan Undang-Undang Perkawinan, Cendekia Hukum, Volume 4, Nomor 2, 2019, http://doi.org/10.33760/jch.v4i2.40.

Laurensius Arliman S, Partisipasi Masyarakat di Daerah Perbatasan NKRI untuk Mencegah Anak Sebagai Objek Human Trafficking, Wawasan Yuridika, Volume 2, Nomor 1, 2018, http://dx.doi.org/10.25072/jwy.v2i1.162.

Laurensius Arliman S, Memperkuat Kearifan Lokal Untuk Menangkal Intoleransi Umat Beragama Di Indonesia, Ensiklopedia of Journal, Volume 1, Nomor 1, 2018, https://doi.org/10.33559/eoj.v1i1.18.

Laurensius Arliman S, Perkawinan Antar Negara Di Indonesia Berdasarkan Hukum Perdata Internasional, Kertha Patrika, Volume 39, Nomor 3, 2017, https://doi.org/10.24843/KP.2017.v39.i03.p03.

Laurensius Arliman S, Komisi Penyiaran Indonesia Sebagai State Auxialiary Bodies Yang Menjamin Siaran Yang Layak Bagi Anak, Veritas et Justitia, Volume 3, Nomor 1, 2017, https://doi.org/10.25123/vej.2528.

Laurensius Arliman S, Partispasi Pemerintah Daerah Di Dalam Perlindungan Anak Yang Berkelanjutan Di Indonesia, Jurnal Ilmu Hukum, Volume 7, Nomor 2, 2016.

Laurensius Arliman S, Sumbangsih Werda Notaris Dalam Organisasi Ikatan Notaris Indonesia, Jurnal Yuridika, Volume 30, Nomor $\quad 3, \quad 2015$, https://doi.org/10.20473/ydk.v30i3.1770. 
Laurensius Arliman S, Peran Dewan Pers Sebagai Lembaga Negara Independen Yang Menjamin Berita Yang Layak Bagi Perlindungan Anak, Mahkamah: Jurnal Kajian Hukum Islam, Volume 4, Nomor 2, 2019, https://doi.org/10.24235/mahkamah.v4i2.4972.

Laurensius Arliman S, Menjerat Pelaku Penyuruh Pengrusakan Barang Milik Orang Lain Dengan Mempertimbangkan Asas Fungsi Sosial Kajian Putusan Nomor 267/Pid. B/2015/PN. Blg, Jurnal Gagasan Hukum, Volume 01, Nomor 1, 2019 ,

Laurensius Arliman S, Partisipasi Masyarakat Di Dalam Pengelolaan Uang Desa Pasca Undang-Undang Nomor 6 Tahun 2014 Tentang Desa, Jurnal Arena Hukum, $\quad$ Volume $\quad$ 12, Nomor $\quad 2, \quad 2019$, https://doi.org/10.21776/ub.arenahukum.2019.01202.5.

Laurensius Arliman S, Pelaksanaan Penyidikian Tindak Pidana Penghinaan Terhadap Agama Melalui Konten Video Melalui Media Sosial, Ensiklopedia Sosial Review, Volume 01, Nomor 1, 2019.

Laurensius Arliman S, Perlindungan Anak dalam Proses Penyidikan di Polresta Padang, Jurnal Ijtihad, Volume 31, Nomor 2, 2015, http://dx.doi.org/10.15548/ijt.v31i2.63,

Laurensius Arliman S, Yulfasni, Tanggung Jawab Perseroan Terbatas Dihubungkan dengan Good Corporate Governance dalam Rangka Mencegah Penyalahgunaan Kekuasaan Pemegang Saham, Pagaruyuang Law Journal, Volume 3, Nomor 1, 2019. 
Laurensius Arliman S, Surat Dakwaan dalam Hukum Acara Pidana Sebagai Bentuk Mendukung Penegakan Hukum di Indonesia, Kosmik Hukum, Volume 19, Nomor 1, 2019, https://doi.org//10.30595/kosmikhukum.v19i1.4081.

Laurensius Arliman S, Mewujudkan Penegakan Hukum Yang Baik Di Negara Hukum Indonesia, Dialogica Jurnalica, Volume 11, Nomor 1, 2019, https://doi.org/10.28932/di.v11i1.1831.

Laurensius Arliman S, Politik Hukum Kenotariatan Pasca Perubahan UndangUndang Jabatan Notaris Bagi Notaris Dalam Menjalankan Jabatannya, Dialogica Jurnalica, Volume 9, Nomor 2, 2018, https://doi.org/10.28932/di.v9i2.976.

Laurensius Arliman S, Mediasi Melalui Pendekatan Mufakat Sebagai Lembaga Alternatif Penyelesaian Sengketa Untuk Mendukung Pembangunan Ekonomi Nasional, UIR Law Review, Volume 2, Nomor 2, 2018, https://doi.org/10.25299/uirlrev.2018.vol2(02).1587.

Laurensius Arliman S, Jaksa Sebagai Pengacara Negara Menurut Undang-undang Kejaksaaan, Jendela Hukum dan Keadilan, Volume 5, Nomor 1, 2018.

Laurensius Arliman S, Pemakzulan Presiden Dan Wakil Presiden Di Indonesia, Justicia et Pax, Volume 34, Nomor 1, 2018, https://doi.org/10.24002/jep.v34i1.1652.

Laurensius Arliman S, Implementasi Keterbukaan Informasi Pubik Untuk Mendukung Kinerja Aparatur Sipil Negara Yang Profesional, Cendikia Hukum, Volume 3, Nomor 2, 2018, http://doi.org/10.33760/jch.v3i2.18. 
Laurensius Arliman S, Peranan Pers Untuk Mewujudkan Perlindungan Anak Berkelanjutan Di Indonesia, Jurnal Ilmu Hukum Tambun Bungai, Volume 2, Nomor 2, 2017.

Laurensius Arliman S, Kedudukan Komisi Perlindungan Anak Indonesia Sebagai State Auxiliary Bodies Dalam Sistem Hukum Ketatanegaraan Indonesia, Justitia et Pax, Volume 32, Nomor 2, 2016, https://doi.org/10.24002/jep.v32i2.1151.

Laurensius Arliman S, Pelaksanaan Penanganan Tindak Pidana Narkotika Oleh Sudbit Keamanan Dengan Subdit Narkotika Kepolisian Daerah Sumatera Barat, Journal of Islamic and Law Studies, Volume 3, Nomor 2, 2019, https://doi.org/10.18592/jils.v3i2.3237.

Laurensius Arliman S, Konsep dan Gagasan Pengenalan Pendidikan Antikorupsi Bagi Anak dalam Rangka Mewujudkan Generasi yang Bebas Korupsi, Nurani: Jurnal Kajian Syari'ah dan Masyarakat, Volume 17, Nomor 1, 2017, https://doi.org/10.19109/nurani.v17i1.1348.

Laurensius Arliman S, Dinamika Dan Gagasan Mencegah Eksploitasi Anak Dalam Pemilihan Umum Kepala Daerah, Jurnal Jentera, Volume 1, Nomor 1, 2017.

Laurensius Arliman S, Perlindungan Terhadap Anak Sebagai Salah Satu Wujud Tujuan Bela Negara, Respublica, Volume 17, Nomor 1, 2017, https://doi.org/10.31849/respublica.v17i1.1453. 
Laurensius Arliman S, Komnas Perempuan Sebagai State Auxialiary Bodies Dalam Penegakan Ham Perempuan Indonesia, Justicia Islamica, Volume 14, Nomor 2, 2017, https://doi.org/10.21154/justicia.v14i2.1228.

Laurensius Arliman S, Hukum Pidana Sebagai Landasan Penegakan Hukum Oleh Penegak Hukum Di Indonesia, Jurnal Jendela Hukum dan Keadilan, Volume 4, Nomor 2, 2017.

Laurensius Arliman S, Politik Hukum Pembentukan Undang-Undang Perlindungan Anak Untuk Mewujudkan Perlindungan Anak Yang Berkelanjutan, Syiar Hukum, Volume 15, Nomor 2, 2017, https://doi.org/10.29313/sh.v15i2.2857. Laurensius Arliman S, Undang-undang 17 Tahun 2016 Tentang Penetapan Perppu 1 Tahun 2016 Sebagai Wujud Perlindungan Anak Ditinjau Dari Perspektif Hukum Tata Negara, Jurnal Hukum Positum, Volume 1, Nomor 2, 2017, http://dx.doi.org/10.35706/positum.v1i2.846.

Laurensius Arliman S, Hak Atas Pengadaan Dan Standar Rumah Bagi Mantan Presiden Dan/Atau Wakil Presiden Republik Indonesia, Jurnal Yuridis, Volume 4, Nomor 1, 2017, http://dx.doi.org/10.35586/.v4i1.131.

Laurensius Arliman S, Pengadilan Hak Asasi Manusia Dari Sudut Pandang Penyelesaian Kasus Dan Kelemahannya, Jurnal Ilmu Hukum Tambun Bungai, Volume 2, Nomor 1, 2017.

Laurensius Arliman S, Pemanggilan Notaris Dalam Rangka Penegakan Hukum Paska Perubahan Undang-Undang Jabatan Notaris, Justicia et Pax, Volume 32, Nomor 1, 2016, https://doi.org/10.24002/jep.v32i1.758. 
Laurensius Arliman S, Perlindungan Hukum Terhadap Anak Yang Tereksploitasi Secara Ekonomi Di Kota Padang, Arena Hukum, Volume 9, Nomor 1, 2016, https://doi.org/10.25123/vej.2076.

Laurensius Arliman S, Tinjauan Kedudukan Pengguna Anggaran dan Kuasa Pengguna Anggaran, Volume 8, Nomor 2, 2015, https://doi.org/10.21776/ub.arenahukum.2015.00802.1.

Laurensius Arliman S, Bolehkan Notaris Melakukan Penyuluhan Hukum Pasar Modal Melalui Media Internet? Jurnal Hukum dan Bisnis (Selisik), Volume 2, Nomor 1, 2016, https://doi.org/10.35814/selisik.v2i1.638.

Laurensius Arliman S, Hak Ingkar (Verschoningsplicht) Atau Kewajiban Ingkar (Verschoning Splicht) Notaris Didalam Undang-Undang Jabatan Notaris, Doctrinal, Volume 1, Nomor 1, 2016.

Laurensius Arliman S, Peranan Filsafat Hukum Dalam Perlindungan Hak Anak Yang Berkelanjutan Sebagai Bagian Dari Hak Asasi Manusia, Doctrinal, Volume 1, Nomor 2, 2016.

Laurensius Arliman S, Partisipasi Aktif dan Pasif Publik dalam Pembentukan Peraturan Daerah di Kota Payakumbuh, Lex Librum: Jurnal Ilmu Hukum, Volume 2, Nomor 1, 2015.

Laurensius Arliman S, Wakil Menteri dalam Sistem Pemerintahan Indonesia, Jurnal Manajemen Sumber Daya Manusia, Volume 2, Nomor 2, 2015. 
Laurensius Arliman S, Dispensasi Perkawinan Bagi Anak Di Bawah Umur Di Pengadilan Agama Padang Sidempuan, Jurnal Al Adalah, Volume 12, Nomor 4, 2015.

Laurensius Arliman S, Implikasi Putusan Mahkamah Konstitusi Dan Perubahan Undang Undang Jabatan Notaris Terhadap Pengawasan Notaris, Jurnal Respublica, $\quad$ Volume $\quad$ 16, Nomor $\quad 1, \quad 2016$, https://doi.org/10.31849/respublica.v16i1.1427.

Laurensius Arliman S, Wacana Program Pembangunan Nasional Semesta Berencana atau GBHN sebagai Landasan Pembangunan Negara Berkelanjutan, Jurnal Manajemen Pembangunan, Volume 3, Nomor 3, 2016.

Laurensius Arliman S, Gagalnya Perlindungan Anak Sebagai Salah Satu Bagian Dari Hak Asasi Manusia Oleh Orang Tua Ditinjau Dari Mazhab Utilitarianisme, Jurnal Yuridis, Volume 3, Nomor 2, 2016, http://dx.doi.org/10.35586/.v3i2.180.

Laurensius Arliman S, Mewujudukan Harmonisasi Lembaga Negara Independen Terhadap Konsep Perlindungan Hak Anak Yang Berkelanjutan, Jendela Hukum dan Keadilan, Volume 3, Nomor 2, 2016.

Laurensius Arliman S, Prostitusi Anak Laki-Laki Sebagai Kegagalan Perlindungan Anak, Istinbath, Volume 3, Nomor 2, 2016.

Laurensius Arliman S, Penyelenggaraan Sistem Presidensil Berdasarkan Konstitusi Yang Pernah Berlaku Di Indonesia, Jurnal Muhakamah, Volume 4, Nomor 2, 2019. 
Melki, Hubungan DPRD dan Pemerintah Daerah Dalam Penetapan Anggaran Pendapatan Dan Belanja Daerah, Soumatera Law Review, Volume 1, Nomor 1, 2018, 10.22216/soumlaw.v1i1.3385.

Muhammad Afif, Penemuan Hukum Oleh Hakim Terhadap Kasus Carok Akibat Sengketa Tanah Dalam Masyarakat Madura, Soumatera Law Review, Volume 1, Nomor 2, 2018, 10.22216/soumlaw.v1i2.3714.

Miszuarty Putri, Pelaksanaan Restitusi Bagi Anak Yang Menjadi Korban Tindak Pidana Sebagai Bentuk Pembaruan Hukum Pidana Berdasarkan Peraturan Pemerintah Nomor 43 Tahun 2017, Soumatera Law Review, Volume 2, Nomor 1, 2019, 10.22216/soumlaw.v2i1.3567.

Muhamad Rasyad, Pembuatan Akta Perdamaian Dalam Penyelesaian Sengketa Tanah Ulayat Melalui Notaris Di Kabupaten Agam, Soumatera Law Review, Volume 2, Nomor 1, 2019, 10.22216/soumlaw.v2i1.3569.

Muhammad Taufiqurrahman, Peran Perancang Peraturan Perundang-Undangan Kementerian Hukum dan Hak Asasi Manusia dalam Pengawasan Produk Hukum Daerah Melalui Executive Preview, Soumatera Law Review, Volume 2, Nomor 2, 2019, 10.22216/soumlaw.v2i2.4341.

Mardalena Hanifah, Perkawinan Beda Agama Ditinjau dari Undang-undang Nomor 1 Tahun 1974 Tentang Perkawinan, Soumatera Law Review, Volume 2, Nomor 2, 10.22216/soumlaw.v2i2.4420. 
Oky Nasrul, Pemanfaatan Tanah Aset PT Kereta Api Indonesia (Persero) Divisi Regional II Sumatera Barat Oleh Pihak Ketiga, Soumatera Law Review, Volume 2, Nomor 1, 2019, 10.22216/soumlaw.v2i1.3554.

Rahmat Fauzi, Perkawinan Campuran Dan Dampak Terhadap Kewarganegaraan Dan Status Anak Menurut Undang-Undang Di Indonesia, Soumatera Law Review, Volume 1, Nomor 1, 2018, 10.22216/soumlaw.v1i1.3395.

Rahmat Fauzi, Faisal, Efektifitas Mediasi Dalam Menyelesaikan Sengketa Perceraian (Study Di Pengadilan Agama Bukittinggi Dan Pengadilan Agama Payakumbuh Tahun 2015-2017), Soumatera Law Review, Volume 1, Nomor 2, 2018, 10.22216/soumlaw.v1i2.3722.

Rahmat Riardo, Konversi Hak Atas Tanah Ulayat Kaum Menjadi Hak Milik Melalui Program Pendaftaran Tanah Sistimatis Lengkap di Kota Solok, Soumatera Law Review, Volume 2, Nomor 2, 2019, 10.22216/soumlaw.v2i2.3566.

Rianda Prima Putri, Pemeriksaan Penggabungan Gugatan Ganti Kerugian Dalam Perkara Pidana Di Pengadilan Negeri Kelas 1B Bukittinggi, Soumatera Law Review, Volume 1, Nomor 1, 2018, 10.22216/soumlaw.v1i1.3348.

Ridwan Putra, Prospek Pembentukan Daerah Istimewa Sumatera Barat Dalam Koridor Negara Kesatuan Republik Indonesia, Soumatera Law Review, Volume 1, Nomor 2, 2018, 10.22216/soumlaw.v1i2.3529.

Rustan Sinaga, Peran Pengadilan Hubungan Industrial Pada Pengadilan Negeri Padang Kelas IA Dalam Memberikan Kepastian Hukum Terhadap Perkara 
Pemutusan Hubungan Kerja, Soumatera Law Review, Volume 1, Nomor 2, 2018, 10.22216/soumlaw.v1i2.3528.

Ratih Agustin Wulandari, Tata Kelola Perusahaan Oleh Direksi PT BPR Dharma Nagari Menerapakan Prinsip Good Corporate Governance, Soumatera Law Review, Volume 2, Nomor 2, 2019, 10.22216/soumlaw.v2i2.3568.

Rusmilawati Windari, Penanggulangan Eksploitasi Seksual Komersial Anak (ESKA) Berdasarkan Global - Local Based Approach (Glocalization), Soumatera Law Review, Volume 2, Nomor 2, 2019, 10.22216/soumlaw.v2i2.4369.

Sayid Anshar, Konsep Negara Hukum dalam Perspektif Hukum Islam, Soumatera Law Review, Volume 2, Nomor 2, 2019, 10.22216/soumlaw.v2i2.4136.

Sandra Dewi, Mengenal Doktrin Dan Prinsip Piercing The Corporate Veil Dalam Hukum Perusahaan, Soumatera Law Review, Volume 1, Nomor 2, 2018, 10.22216/soumlaw.v1i2.3744.

Tommy Busnarma, Penerapan Sanksi Pidana Denda Terhadap Pelaku Tindak Pidana Penyalahgunaan Dan Peredaran Gelap Narkotika Di Pengadilan Negeri Padang, Soumatera Law Review, Volume 2, Nomor 1, 2019, 10.22216/soumlaw.v2i1.3559.

Wahyudi, Tanggungjawab Hukum Apoteker dalam Pemusnahan Obat Narkotika di Rumah Sakit, Soumatera Law Review, Volume 2, Nomor 2, 10.22216/soumlaw.v2i2.4484. 
Yasmirah Mandasari, Sanksi Pidana Terhadap Kandungan Non Halal Terhadap Produk Makanan Bersertifikat Halal Yang Dilakukan Korporasi, Soumatera Law Review, Volume 2, Nomor 2, 2019, 10.22216/soumlaw.v2i2.4339.

Yohanis, Perkawinan Poligami Di Wilayah Hukum Pengadilan Agama Kota Padang (Mekanisime Pemberian Izin, Dasar Hukum, Syarat-Syarat Poligami Dan Pelaksanaanya), Soumatera Law Review, Volume 1, Nomor 1, 2018, 10.22216/soumlaw.v1i1.3403. 